\title{
Professional liability in oral surgery: Legal and medical study of 63 court sentences
}

\author{
Bernardo Perea-Pérez ${ }^{1}$, Andrés Santiago-Sáez ${ }^{2}$, María-Elena Labajo-González ${ }^{3}$, María-Elena Albarrán- \\ Juan ${ }^{4}$
}

\begin{abstract}
${ }^{1}$ Doctor of Medicine. Specialist in Stomatology. Full Professor of the School of Legal and Forensic Medicine of Madrid. School of Medicine. Universidad Complutense de Madrid

${ }^{2}$ Doctor of Medicine. Specialist in Legal and Forensic Medicine Associate Professor of the School of Legal and Forensic Medicine of Madrid. School of Medicine. Universidad Complutense de Madrid

${ }^{3}$ Doctor of Dentistry Doctoral Professor under Contract, Doctor of the School of Legal and Forensic Medicine of Madrid. School of Medicine. Universidad Complutense de Madrid

${ }^{4}$ Doctor of Medicine. Specialist in Legal and Forensic Medicine Associate Professor of the School of Legal and Forensic Medicine of Madrid. School of Medicine. Universidad Complutense de Madrid
\end{abstract}

Correspondence:

Escuela de Medicina Legal de Madrid

Facultad de Medicina. Pabellón 7

Avda. Complutense s/n. 28040. Madrid

elabajo@med.ucm.es

Received: 27/02/2010

Accepted: 06/04/2010
Perea-Pérez B, Santiago-Sáez A, Labajo-González ME, Albarrán-Juan ME. Professional liability in oral surgery: Legal and medical study of 63 court sentences. Med Oral Patol Oral Cir Bucal. 2011 Jul 1;16 (4):e52631.

http://www.medicinaoral.com/medoralfree01/v16i4/medoralv16i4p526.pdf

Article Number: $16885 \quad$ http://www.medicinaoral.com/

(C) Medicina Oral S. L. C.I.F. B 96689336 - pISSN $1698-4447$ - eISSN: $1698-6946$ eMail: medicina@medicinaoral.com

Indexed in:

Science Citation Index Expanded

Journal Citation Reports

Index Medicus, MEDLINE, PubMed

Scopus, Embase and Emcare

Indice Médico Español

\begin{abstract}
Objectives: Dentistry, like all other health care professions, has in recent years been subjected to an increase in legal pressure by patients. Nevertheless, there are areas of activity in dentistry in which, whether because of their frequency or due to the importance of the damage and sequelae claimed, this legal pressure is greater. Amongst these areas of activity is that of oral surgery.

Study design: To be meticulously analyzed in this report are 63 sentences issued by courts of second instance or higher levels regarding lawsuits involving oral surgery. The data collection file includes 13 variables. The descriptive and comparative statistical study by cross-referencing certain variables provides us with a clear and accurate picture of the lawsuit profile.

Results and conclusions: Implantological surgery was the practice subject to the most claims due to surgery (55.6 percent: 35 sentences), and it drew our attention that in $71.4 \%$ of all cases ( 45 sentences) there was a ruling against the professional. The most frequent range of damage payments was between $€ 18,001$ and $€ 60,000$ (40.9\%: 18 sentences), the highest amount having been $€ 24,000$, an important factor to take into account when contracting professional civil liability insurance.
\end{abstract}

Key words: Oral surgery, lawsuit, indemnification amount, implantology. 


\section{Introduction}

The legal pressure against dentists has greatly increased in recent years. To provide one example, during the 25year period spanning from 1982 to 2007, the number of patient claims rose from 1 to 275 (1) in the Ethics Commission of the Professional Association of Region 1.

This legal pressure can take on many forms, from complaints made at the dental practice itself to the filing of lawsuits in court. These lawsuits (mainly civil and criminal) are the most problematic in terms of their potential consequences, especially if action is sought through the criminal courts by filing a criminal complaint.

The causes leading to this increase in legal pressure are numerous, and they include the population's assumption that being healthy and not suffering are effective rights, in addition to having excessive expectations about the results of treatments (frequently due to encouragement by the advertising of large oral/dentistry care chains), the profit motive of many subjects and the increasing use of litigation by society in general (2).

There are few data series available regarding this phenomenon. The objective data are widely dispersed and difficult to access (due to the restrictions created by Constitutional Law 15/1999 on the Protection of Information of a Personal Nature, and due to the corporate interests of the entities themselves which keep the information). The most reliable series available to us are those which originate from the ethical commissions of professional associations (3). These are very complete series, but they are biased due to the internal objectives pursued by these very institutions.

As for the fields of dentistry for which there are most claims, in practically all data series the same trends are found. The activities subject to most claims are usually implantology, prosthodontics, orthodontics and endodontics. Oral surgery does not usually appear amongst the activities subject to the largest number of claims. Special attention is merited by implantology (in both its surgical and prosthodontic facets), which appears as the dental activity subject to most claims in the most recent series. The data on the year of 2008, from the Ethics Commission of the Professional Association of Region 1 (4), regarding a total number of 256 claims by patients, shows that the activities subject to the greatest number of claims are implantology (60 cases, $23.43 \%$ of the total), fixed prostheses (50 cases, $19.53 \%$ of the total), endodontics ( 45 cases, $17.57 \%$ of the total) and orthodontics (28 cases, $10.93 \%$ of the total). Oral surgery was the seventh most important field in terms of claims filed (13 cases, $5.07 \%$ of the total). In this series, the data corresponding to implantology did not distinguish between problems that arose in the surgical and prosthodontic stages. Other series also show similar data (5-8). For example, in the United States, from 1999-2004, the percentage of legal claims against dentists due to surgi- cal activities was 9.4\% (9); a similar study carried out from 1989 to 1992 showed a percentage of $21.86 \%$, and in Mexico, during the years of 2001 and 2002, the figure was $15.8 \%(10)$.

Although the activities related with oral surgery, in any of its forms, are not frequently the subject of claims before ethical commissions, due to their special characteristics and the damages which they may cause (11), doubt does arise regarding their frequency and importance in the case of lawsuits in courts.

The objective of this study is to discover the frequency of lawsuits filed against dentists as a result of oral surgery treatments, the causes of those claims, the circumstances surrounding them and the results.

\section{Materials and Methods}

This study was performed using 63 court sentences regarding oral surgery treatments provided by dentists.

The sentences were selected from the "Westlaw Aranzadi" legal database and the CENDOJ (search engine of the jurisprudence system of the General Council of the Spanish Judiciary). These sentences were issued by courts of the second and third instance (Provincial Courts, Superior Justice Courts of Autonomous Regions, the Audiencia Nacional and the Supreme Court) in the Civil, Criminal and Contentious-Administrative jurisdictions. All of these sentences were issued in the time period spanning from 1993 to 2007.

The criteria for inclusion taken into consideration were as follows:

- Sentences issued on the appropriateness of an oral surgery treatment carried out by a dentist. Oral surgery treatments were considered to be all those included in the contents and competences established for this field in the "White Book of the University Degree of Grado in Dentistry" published by the ANECA (National Agency for Quality Evaluation and Accreditation) (12). Due to their special relevance, surgical treatments involving implantological procedures were distinguished.

- Sentences which contained clear data regarding the treatment provided, the parties responsible for the treatment and the consequences for the patient.

Of the total number of 1,899 sentences involving health care treatments included in the aforementioned databases, 144 were the result of dental/stomatological treatments, and of these 63 involved oral surgery treatments which met the criteria for inclusion in the study.

From these sentences, information was taken regarding:

- Type of court.

- Jurisdiction (Civil, Criminal or Contentious-Administrative).

- Year of the sentence.

- Autonomous region where the treatment was provided. 
- Sex of the patient who filed the claim.

- Patient age (minor or non-minor).

- Gender of the professional (s).

- Whether the sentence found that there was malpractice.

- Amount of the indemnification/damages awarded (if any).

- Existence of deficiencies in patient information and/ or consent.

- Type of problem which occurred.

- Damages and sequalae claimed.

- Type of health care center where the dental care was provided.

The statistical analysis was performed using version 13.0 of the SPSS program. This work was given authorization by the Ethics Commission of the Illustrious Official Association of Dentists and Stomatologists of Region 1.

\section{Results}

The general data on the court sentences studied show that $96.8 \%$ (61 cases) were filed under the Civil jurisdiction, while $3.2 \%$ ( 2 cases) did so in the Criminal jurisdiction. Of all cases, 92.1\% (58 cases) were sentences handed down by the Provincial Courts, while 7.9\% (5 cases) were sentences by the Supreme Court. As for the geographical origins of the sentences by province, though there was a great deal of dispersion, the most notable were Madrid (17.5\% of all cases: 11 sentences), Barcelona (11.1\% of all cases: 7 sentences), Asturias (6.3\% of all cases: 4 sentences) and Cantabria (6.3\% de las sentences: 4 sentences). Since the first year of the series (1993), the frequency of sentences involving oral surgery has been on the rise, with the largest number in the last period studied: 2003-07 (36 sentences: 57.14\% of all cases) (Fig. 1).

As for the results of the court sentences, in 71.4\% (45 sentences) of cases the sentence was issued against the professional, while in $28.6 \%$ (18 sentences) the professional was acquitted. The text of the sentences expressly mentions flaws in providing information or the lack of a consent document in 34.9\% (22 sentences) of cases, and the obligation of achieving a result in 55.6\% (35 sentences). The amounts of the indemnifications/damages awarded in those cases in which there was a sentence against the professional and the amount is stated in the sentence ( 44 cases) can be broken down into the following ranges: up to $€ 6,000$ (25\%: 11 sentences), from $€ 6,001$ to $€ 18,000$ ( $25 \%$ : 11 sentences), from $€ 18,001$ to $€ 60,000$ (40.9\%: 18 sentences), and more than $€ 60,000$ (9.01\%: 4 sentences). The largest indemnification in this series was equal to $€ 240,000$ (Fig. 2).

As for the field within surgery involved in the claim, implantological surgery was that with the most claims (55.6\%: 35 sentences), compared with all other activities in oral surgery (44.4\%: 28 cases). Amongst the grounds for the claims (Table 1), damage to anatomical structures was the most frequent cause $(66.6 \%$ : 42 sentences), followed by repetition of the treatment (33.3\%: 21 sentences) (Fig. 3). Amongst the anatomical damages, the type with the most claims was injury of the lower dental nerve (30.95\%: 13 sentences), followed by complications which required hospitalization (16.6\%: 7 sentences) (Table 1).

Evolución del número de las sentencias por quinquenios

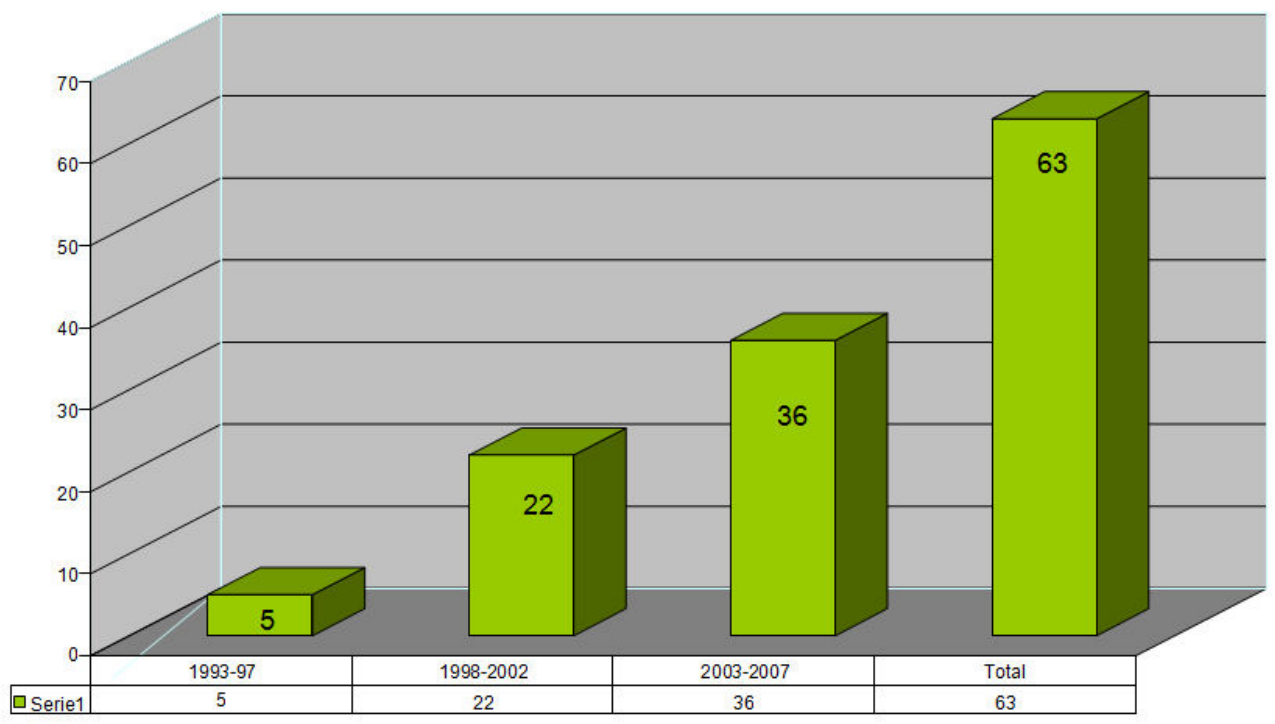

Fig. 1. Chronological changes in sentences. 
Table 1. Damage to anatomical structures.

\begin{tabular}{|l|c|}
\hline \multicolumn{1}{|c|}{ Table 1 } & $\begin{array}{c}\text { Damage to } \\
\text { anatomical structures }\end{array}$ \\
\hline Damage to lower dental nerve & $13(30.95 \%)$ \\
\hline Complication with hospital admittance & $7(16.66 \%)$ \\
\hline Tooth loss & $6(14.28 \%)$ \\
\hline Damage to lingual nerve & $5(11.90 \%)$ \\
\hline ATM damage & $4(9.52 \%)$ \\
\hline Death & $4(9.52 \%)$ \\
\hline Oral-sinus connection & $2(4.76 \%)$ \\
\hline Complete loss of jaw bone & $1(2.38 \%)$ \\
\hline Total & $42(100 \%)$ \\
\hline
\end{tabular}

Table 2. Cross-reference of sentence date and specialty.

\begin{tabular}{|c|c|c|c|}
\hline Table 2 & Oral Surgery & Implantology & total \\
\hline $1993-1997$ & $4(80 \%)$ & $1(20 \%)$ & $5(100 \%)$ \\
\hline $1998-2002$ & $13(59.09 \%)$ & $9(40.90 \%)$ & $22(100 \%)$ \\
\hline $2003-2007$ & $11(30.55 \%)$ & $25(69.44 \%)$ & $36(100 \%)$ \\
\hline Total & $28(44.44 \%)$ & $35(55.55 \%)$ & $63(100 \%)$ \\
\hline
\end{tabular}

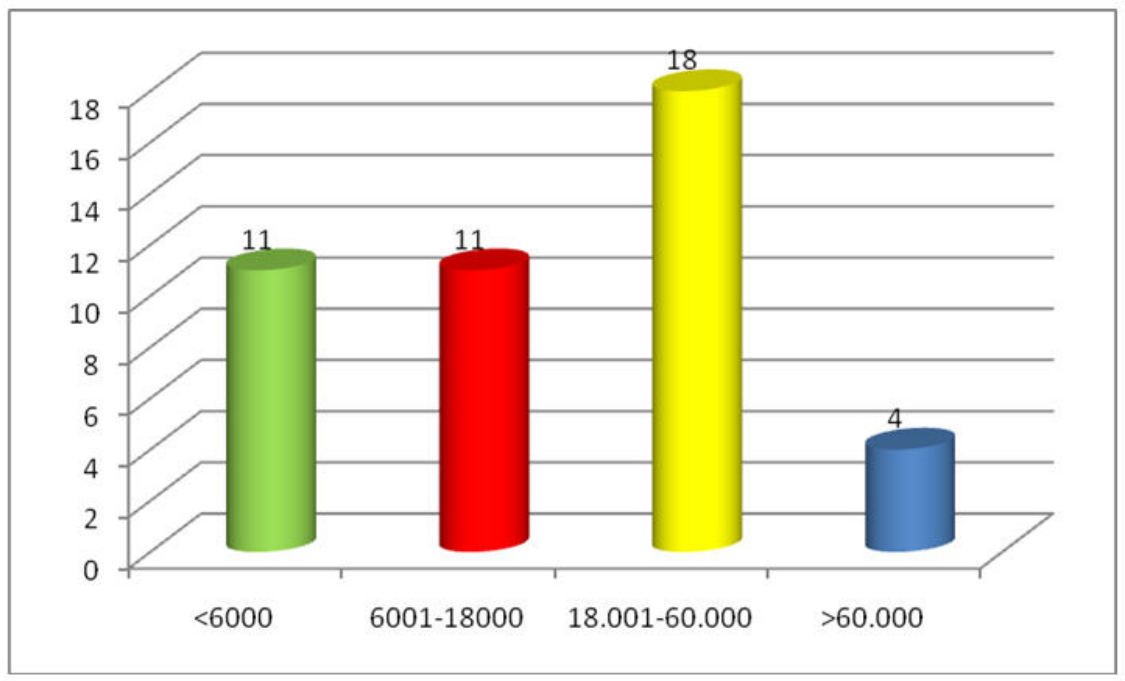

Fig. 2. Amount of damages awarded in sentences.

Daños y secuelas reclamadas

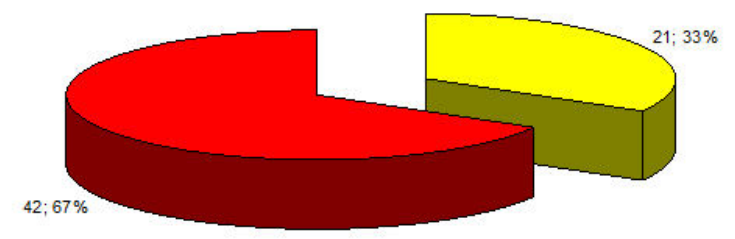

Fig. 3. Damages and sequelae claimed. 
In terms of the characteristics of the patient claimant and the professional defendant, the patient claimants were divided equally in terms of their gender (31 men and 32 women). However, the same was not true for the gender of the professional defendants, most of whom were males (84.1\%: 53 sentences). The care was provided in a dental clinic in $85.7 \%$ of all cases (54 sentences), and on $36.5 \%$ of all occasions (23 sentences) the company which owned the clinic or the dental care insurer with which the clinic had an agreement was also sued.

When comparing the variables obtained upon crossreferencing the type of surgical activity and the amount of the indemnification, the greater amount of indemnifications was notable in sentences involving implantological surgery. In the interval of indemnifications from $€ 18,001$ to $€ 60,000$ (18 sentences), $77.7 \%$ correspond to cases of implantological surgery.

Upon cross-referencing the year of the sentence and the type of oral surgery activity, we found a notable increase in the number of sentences involving implantological surgery in the last of the time periods examined (Table 2).

\section{Discussion}

First of all, we must emphasize the lack of comparable data existing in the scientific literature. While the number of studies on claims against dentists is very low, those specifically regarding oral surgery are practically non-existent.

Due to this lack of studies in the literature and the great dispersion of and difficult access to information, the choice was made to use court sentences included in legal records. The problem with this type of sample is that these are sentences of the second instance (therefore, data from courts of first instance are lost), creating a partial bias in the results. This bias explains why $96.8 \%$ of the sentences belong to the jurisdiction of the Civil courts, while 92.1\% were issued by Provincial Courts. We believe that the rest of the data in this study is affected little or not at all by this bias.

Although the sentences regarding oral surgery treatments do not appear amongst those with the most claims, we must bear in mind the frequency of the surgical interventions (considerably less than other types of dental interventions) in order to estimate their true legal hazardousness. We must also bear in mind that the damages claimed are usually greater in amount.

It is of interest to point out the high percentage of sentences against professionals $(71.4 \%)$, and the high percentages which refer to the obligation of providing results and the lack of informed consent. Though there are no comparable data in the scientific literature, this coincides with the authors' experience. Most court sentences are based on the failure to achieve the expected results (especially when involving implantological sur- gery), coupled with flaws in providing information or obtaining consent. In terms of indemnification amounts, most fluctuate within the interval of $€ 18,001$ to $€ 60,000$. These are considerably lower amounts than those seen in other fields of medicine. It is also of interest to point out that there is a large discrepancy between the common maximum amounts of professional civil liability insurance policies (usually at approximately $€ 300,000$ ) and the amounts awarded by the courts for damages.

The fact that implantological surgery leads to a greater number of claims in court than do other surgical interventions performed in the oral cavity is a piece of information that coincides with those in other series. This increase has also accelerated in recent years. The most recent data indicate that implantological treatments (whether for surgical or prosthodontic purposes) have become the number one reason behind dental patient claims (4). The damage to anatomical structures most frequently described in court sentences is damage to the lower dental nerve.

One curious piece of data from the study is that nearly $85 \%$ of all the professionals subjected to complaints or lawsuits are males. This information coincides with that found in another study that was carried out specifically for implantology at the Professional Association of Region 1. Nevertheless, this is not in line with a profession in which the presence of women is increasing in importance. At the present time $54 \%$ of the members of the Professional Association of Region 1 are women (1, 3-4).

In conclusion, this study would like to underline, on the basis of the sentences studied, the potential legal hazards involved in treatments for surgery of the mouth, especially those involving implantology. This should force us to be especially carefully in terms of ensuring the existence of a full clinical history containing the proper radiographical records. It also justifies the indispensable need for having proper information on each situation which arises, with the appropriate informed consent document signed by the patient before carrying out any surgical procedure. In the period studied, the amount of the indemnifications resulting from oral surgery procedures in no case surpassed the common coverage limits of professional civil liability insurance policies.

\section{References}

References with links to Crossref - DOI

1. Perea B. Memoria 2007 de la Comisión Deontológica del Ilustre Colegio Oficial de Odontólogos y Estomatólogos de la I Región. COEM. [monographic on the Internet] Madrid: Colegio de Odontólogos y Estomatólogos de la I Región; 2007 [cited May 2009]. Available in: http://www.coem.org.es/index.php?option=com_conte nt\&task $=$ view\&id $=33 \&$ Itemid $=70$.

2. Consejo General del Poder Judicial. España: Consejo General del Poder Judicial; 2008 [cited May 2009]. Memoria anual 2008. Availablein:http:// www.poderjudicial.es/eversuite/GetRecords?Template=cgpj/cgpj/ principal.htm. 
3. Vega JM, Perea B. Memoria de reclamaciones durante el periodo 1996-2002 de la Comisión Deontológica del Ilustre Colegio Oficial de Odontólogos y Estomatólogos de la I Región. COEM. [monographic on the Internet] Madrid: Colegio de Odontólogos y Estomatólogos de la I Región [cited May 2009]. Available in: http://www.coem.org. es/index.php?option $=$ com_content $\&$ task $=$ view\&id $=33 \&$ Itemid $=70$. 4. Perea B. Memoria $200 \overline{8}$ de la Comisión Deontológica del Ilustre Colegio Oficial de Odontólogos y Estomatólogos de la I Región. COEM. [monographic on the Internet] Madrid: Colegio de Odontólogos y Estomatólogos de la I Región [cited May 2009].

Available in: http://www.coem.org.es/index.php?option=com conte nt\&task= view\&id=33\&Itemid $=70$.

5. Kriisa M. Swedish malpractice reports and convictions. Qual Assur Health Care. 1990;2:329-34.

6. René N, Owall B. Dental malpractice in Sweden. J Law Ethics Dent. 1991;4:16-31.

7. René N, Westesson PL, Owall B. Complaint and disciplinary systems in dentistry in Sweden: a presentation and discussion of their efficacy in preventing malpractice. Qual Assur Health Care. 1993;5:187-99.

8. Cronström R, Owall B, René N. Treatment injuries in dentistry-cases from one year in the Swedish Patient Insurance Scheme. Int Dent J. 1998;48:187-95.

9. Shulman JD, Sutherland JN. Reports to the National Practitioner Data Bank involving dentists, 1990-2004. J Am Dent Assoc. 2006; 137:523-8

10. Milgrom P, Fiset L, Whitney C, Conrad D, Cullen T, O'Hara D. Malpractice claims during 1988-1992: a national survey of dentists. J Am Dent Assoc. 1994;125:462-9.

11. Carrotte PV. Most compensation claims concern restorative or oral surgery procedures. Br Dent J. 1998;184:123.

12. Agencia Nacional de Evaluación de la Calidad y Acreditación (ANECA). Madrid: Agencia Nacional de Evaluación de la Calidad y Acreditación (ANECA); 2004 [Cited May 2009]. Sanz M. Libro blanco de título de grado de odontología [198]. Available in: http:// www.aneca.es/media/150344/libroblanco_odontologia_def.pdf. 